\title{
EVALUASI PROSEDUR PEMUNGUTAN DAN PENERAPAN AKUNTANSI PAJAK HOTEL PADA BIG FISH HOTEL MANADO
}

\author{
Glenn Rotinsulu ${ }^{1}$, Harijanto Sabijono² Stanley Kho Walandouw ${ }^{3}$ \\ 1,2,3 Jurusan Akuntansi, Fakultas Ekonomi dan Bisnis, Universitas Sam Ratulangi, Jl. Kampus Bahu, Manado, \\ 95115, Indonesia
}

Email : glenn_rotinsulu@yahoo.com

\begin{abstract}
In increasing the number of members in tax revenue, the government is always trying to find objects of taxes that can contribute to the achievement of tax revenue. Hotel tax is one part of local taxes that have the potential to continue to grow along with support issues such as services, development and tourism in regional development policies. This study aims to evaluate the procedure of collection and application of hotel tax accounting conducted at Big Fish Hotel Manado. The type of research used in this study is descriptive qualitative research. The results of this study indicate that the implementation of hotel tax collection procedure at Big Fish Hotel Manado is in accordance with Manado City Local Regulation Number 2 Year 2011 on Regional Tax and for hotel tax accounting record has been in accordance with Statement of Financial Accounting Standards (PSAK) No. 23 on Revenue.

Keywords : hotel tax collection, hotel tax accounting, local tax, PSAK No. 23
\end{abstract}

\section{PENDAHULUAN}

Dalam meningkatkan penerimaan negara terutama dalam penerimaan pajak, pemerintah selalu berusaha mencari objek-objek pajak yang dapat memberikan kontribusi agar tercapainya penerimaan pajak. Di Indonesia sendiri sejak reformasi perpajakan digulirkan pada tahun 1983, penerimaan pajak telah meningkat secara signifikan dari tahun ke tahun. Pajak menjadi tolok ukur sampai sejauh mana suatu negara dapat membiayai pengeluaran-pengeluaran negara dengan mandiri.

Pemungutan pajak di Indonesia dilakukan oleh pemerintah pusat dan pemerintah daerah. Pajak yang kewenangan pemungutannya berada di tangan pemerintah pusat dinamakan pajak negara, sedangkan pajak yang kewenangan pemungutannya berada di tangan pemerintah daerah disebut pajak daerah. Secara umum perpajakan di Indonesia terbagi menjadi dua, yaitu pajak pusat dan pajak daerah. Secara resmi era otonomi daerah berlaku di Indonesia sejak 1 Januari 2001 sehingga daerah dituntut mencari berbagai alternatif sumber penerimaan yang dapat digunakan untuk membiayai pengeluaran atau belanja daerah. Pemberian kewenangan kepada daerah untuk memungut pajak daerah diperlukan adanya landasan hukum berupa undang-undang. Sebagai landasan hukum yang merupakan dasar hukum pungutan pajak daerah yaitu Undang-Undang Nomor 18 Tahun 1997 tentang Pajak Daerah dan Retribusi Daerah sebagaimana telah diubah terakhir dengan Undang-Undang Nomor 28 Tahun 2009 yang berlaku sejak 1 Januari 2010.

Sistem yang digunakan dalam pemungutan pajak daerah secara umum adalah self assessment system. Hal ini dapat dilihat pada ketentuan Undang-Undang Nomor 34 Tahun 2000 yang menentukan bahwa pajak dipungut berdasarkan penetapan kepala daerah atau dibayar sendiri oleh wajib pajak. Dalam pelaksanaannya, pemungutan pajak daerah tidak dapat diserahkan pihak ketiga. Big Fish Hotel Manado adalah salah satu perusahaan jasa dalam industri perhotelan dibawah naungan PT. Sari Murni Putra dengan kategori hotel budget. Hotel ini bertanggung jawab atas pengelolaan pajak hotel yang perlu mengupayakan optimalisasi dalam pemungutan guna memperoleh pendapatan daerah yang cukup besar 
untuk pembangunan daerah di Kota Manado. Perusahaan ini menerapkan suatu kebijakan dalam pencatatan pengakuan pendapatan akuntansi pajak hotel, yaitu net income. Artinya pendapatan yang tercatat dan diakui adalah nilai bersih income setelah dikurangi dengan tax and service charge, sehingga menarik untuk dilakukan penelitian mengenai bagaimana prosedur pemungutan dan penerapan akuntansi pajak hotel apakah telah sesuai dengan undang-undang perpajakan dan standar akuntansi keuangan yang berlaku di Indonesia. Tujuan penelitian ini adalah untuk mengetahui prosedur pemungutan dan penerapan akuntansi pajak hotel pada Big Fish Hotel Manado.

\section{TINJAUAN PUSTAKA}

\subsection{Akuntansi}

Pengertian akuntansi menurut Lubis (2015:2) adalah sistem informasi yang menyediakan laporan bagi para pihak pengambil keputusan (stakeholder) mengenai aktivitas ekonomi dan kondisi perusahaan. Akuntansi menurut Horgren (2012:215) adalah sebuah sistem informasi yang mengatur aktivitas bisnis, pemrosesan data menjadi laporan dan mengkomunikasikan hasilnya pada para pengambil keputusan. Pontoh (2013:10) mengemukakan bahwa akuntansi pada umumnya sering disebut bahasa bisnis dan akuntansi pada dasarnya akan menghasilkan informasi dari sebuah sistem akuntansi yang ada di dalam sebuah entitas atau organisasi bisnis yang disebut dengan informasi akuntansi yang akan dimanfaatkan oleh pengguna seperti masyarakat intelektual dan para pengambil keputusan bisnis dalam organisasi.

\subsection{Pajak}

Proses akuntansi dimulai adanya transaksi, yaitu peristiwa yang dapat mengakibatkan berubahnya posisi keuangan perusahaan. Transaksi inilah yang menjadi atensi pemerintah dalam mengeluarkan peraturan-peraturan perpajakan agar dapat memungut pajak atas transaksi untuk membiayai pembangunan di Indonesia (Lubis 2015:2). Dengan adanya titik ketersinggungan akuntansi pajak ini, yaitu transaksi, perusahaan cenderung menerapkan akuntansi yang sudah sesuai dengan peraturan pajak atau disebut dengan istilah akuntansi pajak (Tax Accounting).

\subsection{Pajak Daerah}

Menurut Priantara (2013:535) Pajak daerah secara umum adalah kontribusi wajib pajak kepada daerah yang terutang oleh orang pribadi atau badan yang bersifat memaksa berdasarkan undang-undang dengan tidak mendapat imbalan yang secara langsung dan digunakan untuk keperluan daerah bagi kemakmuran rakyat.

\subsection{Pajak Hotel}

Wisanggeni (2015:16) Pajak hotel adalah pajak yang dipungut atas pelayanan yang disediakan hotel termasuk jasa penunjang sebagai kelengkapan hotel yang sifatnya memberikan kemudahan termasuk fasilitas olahraga dan hiburan.

\section{Pengukuhan Wajib Pajak}

Siahaan (2016:308-309) menyebutkan bahwa wajib pajak hotel wajib melakukan pendaftaran usahanya kepada bupati/walikota, dalam praktik umumnya kepada dinas pendapatan daerah kabupaten/kota, dalam jangka waktu tertentu, misalnya selambatlambatnya tiga puluh hari sebelum dimulainya kegiatan usaha, untuk dikukuhkan dan diberikan Nomor Pokok Wajib Pajak Daerah (NPWPD). Jangka waktu ini sesuai dengan jangka waktu yang ditentukan oleh bupati/walikota dimana pajak hotel dipungut.

\section{Pendaftaran dan Pendataan}

Siahaan (2016:309) Untuk mendapatkan data wajib pajak dilaksanakan pendaftaran dan pendataan terhadap wajib pajak. Kegiatan pendaftaran dan pendataan diawali dengan mempersiapkan dokumen yang diperlukan, berupa formulir pendaftaran dan pendataan, kemudian diberikan kepada wajib pajak. Setelah dokumen disampaikan kepada wajib pajak, 
wajib pajak mengisi formulir pendaftarkan dengan jelas, lengkap, serta mengembalikan kepada petugas pajak. Selanjutnya, petugas pajak mencatat formulir pendaftaran dan pendataan yang dikembalikan oleh wajib pajak, dalam daftar induk wajib pajak berdasarkan nomor urut yang digunakan sebagian dasar untuk menerbitkan NPWPD.

\section{Pelaporan Pajak dan Surat Pemberitahuan Pajak Daerah (SPTPD)}

Siahaan (2016:309-310) Wajib pajak hotel wajib melaporkan kepada bupati/walikota, dalam praktik sehari-hari adalah kepada kepala dinas pendapatan daerah kabupaten/kota, tentang penghitungan dan pembayaran pajak hotel terutang. Wajib pajak yang telah memiliki NPWPD setiap awal masa pajak mengisi SPTPD. SPTPD diisi dengan jelas, lengkap, dan benar serta ditandatangani oleh wajib pajak atas kuasanya dan disampaikan kepada walikota/bupati atau pejabat yang ditunjuk sesuai dengan jangka waktu yang ditentukan. Umunya SPTPD harus disampaikan selambat-lambatnya lima belas (15) hari setelah berakhirnya masa pajak. Seluruh data perpajakan yang diperoleh dari daftar isian tersebut dihimpun dan dicatat atau dituangkan dalam berkas atau kartu data yang merupakan hasil akhir yang akan dijadikan sebagai dasar dalam perhitungan dan penetapan pajak yang terutang. Keterangan dan dokumen yang harus dicantumkan dan atau dilampirkan pada SPTPD ditetapkan oleh bupati/walikota.

\section{Pemungutan Pajak Hotel}

Siahaan (2016:310-311) Pemungutan pajak hotel tidak dapat diborongkan. Artinya, seluruh proses kegiatan pemungutan pajak hotel tidak dapat diserahkakn kepada pihak ketiga. Walaupun demikian, dimungkinkan adanya kerja sama dengan pihak ketiga dalam proses pemungutan pajak antara lain, pencetakan formulir perpajakan, pengiriman surat-surat kepada wajib pajak, atau penghimpunan data objek dan subjek pajak.

\section{Penetapan Pajak Hotel}

Siahaan (2016:311-312) Setiap pengusaha hotel (yang menjadi wajib pajak) wajib menghitung, memperhitungkan, membayar, dan melaporkan sendiri pajak hotel yang terutang dengan menggunakan SPTPD. Ketentuan ini menunjukkan sistem pemunguta//n pajak hotel pada dasarnya merupakan self assessment system, yaitu wajib pajak diberikan kepercayaan penuh untuk menghitung, memperhitungkan, membayar dan melaporkan sendiri pajak yang terutang. Dengan pelaksanaan sistem pemungutan ini petugas dinas pendapatan daerah kabupaten/kota, yang ditunjuk oleh bupati/walikota menjadi fiskus, hanya bertugas mengawasi pelaksanaan pemenuhan kewajiban pajak oleh wajib pajak. Berdasarkan SPTPD yang disampaikan oleh wajib pajak dan pendataan yang dilakukan oleh petugas dinas pendapatan daerah, bupati/walikota atau pejabat yang ditunjuk oleh bupati/walikota menetapkan pajak hotel yang terutang dengan menerbitkan surat ketetapan pajak daerah (SKPD). SKPD harus dilunasi oleh wajib pajak paling lama tiga puluh (30) hari sejak diterimanya SKPD oleh wajib pajak atau jangka waktu lain yang ditetapkan oleh bupati atau walikota.

\section{Surat Tagihan Pajak Daerah (STPD)}

Siahaan (2016:312) bupati/walikota dapat menerbitkan Surat Tagihan Pajak Daerah (STPD) jika pajak hotel dalam tahun berjalan atau kurang dibayar. STPD diterbitkan baik terhadap wajib pajak yang melakukan kewajiban pajak yang dibayar sendiri maupun terhadap wajib pajak yang melaksanakan kewajiban pajak yang dipungut. Sanksi administrasi berupa bunga dikenakan dikenakan kepada wajib pajak yang tidak atau kurang membayar pajak terutang.

\section{Pembayaran Pajak Hotel}

Siahaan (2016:314-315) pajak hotel terutang dilunasi dalam jangka waktu yang ditentukan dalam peraturan daerah, misalnya selambat-lambatnya pada tanggal 15 bulan berikutnya dari masa pajak yang terutang setelah berakhirnya masa pajak. Penentuan tanggal jatuh tempo pembayaran dan penyetoran pajak hotel ditetapkan oleh bupati/walikota. Apabila 
kepada wajib pajak diterbitkan SKPDKB, SKPDKBT, STPD, surat keputusan pembetulan, surat keputusan keberatan, dan putusan banding yang menyebabkan jumlah pajak yang harus dibayar bertambah, pajak hotel yang dilunasi paling lambat 1 (satu) bulan sejak tangal diterbitkan. Pembayaran pajak hotel yang terutang dilakukan ke kas daerah, bank, atau tempat lain yang ditunjuk oleh bupati/walikota sesuai waktu yang ditentukan oleh SKPD, SKPDKB, SKPDKBT, dan SPTD. Pembayaran pajak dilakukan dengan menggunakan Surat Setoran Pajak Daerah (SSPD). Pembayaran pajak harus dilakukan sekaligus atau lunas. Kepada wajib pajak yang melakukan pembayaran pajak diberikan tanda bukti pembayaran pajak dan dicatat dalam buku penerimaan. Hal ini harus dilakukan oleh petugas tempat pembayaran pajak untuk tertib administrasi dan pengawasan penerimaan pajak. Dengan demikian, pembayaran pajak akan mudah terpantau oleh petugas dinas pendapatan daerah. Bentuk, isi, ukuran buku penerimaan, dan tanda bukti pembayaran pajak ditetapkan dengan keputusan bupati/walikota. Bupati/walikota atau pejabat yang ditunjuk dapat memberikan persetujuan kepada wajib pajak untuk mengangsur pembayaran pajak hotel terutang dalam kurun waktu tertentu setelah memenuhi persyaratan yang ditentukan. Pemberian persetujuan untuk mengangsur pembayaran pajak diberikan atas permohonan wajib pajak.

\section{Penagihan Pajak Hotel}

Siahaan (2016:315-316) Apabila pajak hotel yang terutang tidak dilunasi setelah jatuh tempo pembayaran, bupati/walikota atau pejabat yang ditunjuk akan melakukan tindakan penagihan pajak. Penagihan pajak dapat dilakukan dengan memberikan surat teguran atau surat peringatan atau surat lain yang sejenisnya sebagai awal untuk tindakan penagihan pajak. Surat teguran dikeluarkan tujuh hari sejak jatuh tempo pembayaran pajak dan dikeluarkan oleh pejabat yang ditunjuk oleh bupati/walikota. Dalam jangka waktu tujuh 7 hari sejak surat teguran atau surat lain yang sejenis diterima, wajib pajak harus melunasi pajak yang terutang. Pembukuan Pajak Hotel

Siahaan (2016:320-321) wajib pajak hotel dengan peredaran usaha tertentu, umunya Rp. 300.000.000,00 per tahun keatas, wajib menyelenggarakan pembukuan, yang menyajikan keterangan yang cukup untuk menghitung harga perolehan, harga jual, dan harga penggantiann dari penjualan makanan dan minuman. Wajib pajak yang tidak diwajibkan membuat pembukuan yaitu wajib pajak yang peredaran usahanya kurang dari jumlah yang ditentukan, tetap diwajibkan menyelenggarakan pencatatan nilai peredaran usaha secara teratur, yang menjadi dasar pengenaan pajak. Pencatatan harus dilakukan dengan sebaikbaiknya yang menggambarkan suatu keadaan atau kegiatan usaha yang sebenarnya.

\section{Pemeriksaan Pajak Hotel}

Siahaan (2016:321) Pemeriksaan pajak hotel dilakukan oleh pejabat yang berwenang untuk menguji kepatuhan pemenuhan kewajiban perpajakan daerah dan tujuan lain dalam rangka melaksanakan peraturan daerah tentang pajak hotel. Pelaksanaan pemeriksaan oleh petugas yang ditunjuk oleh bupati/walikota atau pejabat yang berwenang sedangkan untuk keperluan pemeriksaan, petugas pemeriksa harus dilengkapi dengan tanda pengenal pemeriksa dan surat perintah pemeriksaan serta harus memperlihatkannya kepada wajib pajak yang diperiksa.

\subsection{Pendapatan}

\section{Pengukuran Pendapatan}

Menurut PSAK No. 23 pendapatan diukur dengan nilai wajar imbalan yang diterima atau dapat diterima. Jumlah pendapatan yang timbul dari transaksi biasanya ditentukan oleh persetujuan antara entitas dengan pembeli atau pengguna aset tersebut. Jumlah tersebut diukur pada nilai wajar imbalan yang diterima atau dapat diterima dikurangi jumlah diskon usaha dan volume yang diperbolehkan oleh entitas

\section{Pengungkapan}

Menurut PSAK No. 23 menyebutkan bahwa entitas mengungkapkan : 
a) Kebijakan akuntansi yang digunakan untuk pengakuan pendapatan termasuk metode yang digunakan untuk menentukan tingkat penyelesaian transaksi penjualan jasa.

b) Jumlah setiap kategori signifikan dari pendapatan yang diakui selama periode tersebut termasuk pendapatan yang berasal dari :

1) Penjualan barang.

2) Penjualan jasa.

3) Bunga.

4) Royalti.

5) Dividen.

c) Jumlah pendapatan yang berasal dari pertukaran barang atau jasa yang tercakup dalam setiap kategori yang signifikan dari pendapatan.

\section{Pengakuan dan Pengukuran}

Menurut PSAK No. 23 penentuan apaakh entitas bertindak sebagai partisipal atau agen. Paragraf 08 menyatakan bahwa dalam hubungan keagenan, arus kas masuk bruto manfaat ekonomik meliputi jumlah yang ditagih untuk kepentingan principal dan tidak mengakibatkan kenaikan ekuitas entitas. Jumlah yang ditagih atas nama principal bukan merupakan pendapatan. Sebaliknya, yang merupakan pendapatan adalah jumlah korelasi yang diterima. Penentuan apakah entitas bertindak sebagai principal atau agen mensyaratkan adanya pertimbangan dan penilaian dari seluruh fakta dan kondisi yang relevan.

\section{Pencatatan Akuntansi Pajak Hotel}

Pada proses pengukuran jumlah pajak hotel, yang dicatat adalah sebesar 10\% (sepuluh persen) dari jumlah tagihan. Pajak hotel termasuk sebagai pajak tidak langsung, dalam artian pihak hotel yang bertindak sebagai pemungut pajak hotel dari subjek pajak yaitu tamu hotel, yang kemudian akan disetor kepada pemerintah daerah Puspita (2012:19-20). Karena pihak hotel hanyalah bertindak sebagai pemungut dan pajak yang berhasil dipungut nantinya harus disetor ke kas daerah, maka hotel mencatat pajak hotel tersebut pada pos hutang pajak yang termasuk sebagai hutang lancer karena harus disetor dalam jangka waktu 30 hari sejak saat terutangnya pajak. Pajak hotel diakui terutang pada saact hotel melakukan penagihan kepada subjek pajak.

Selain dipungut pajak hotel, biasanya hotel juga akan mengenakan tambahan biaya service charge terhadap tamu hotel sebesar 10\% (sepuluh persen). Tambahan biaya service charge ini juga bukan merupakan hak hotel melainkan merupakan hak karyawan yang bisa dianggap sebagai tips atas pelayanannya kepada tamu hotel. Karena service charge tersebut bukan merupakan hak hotel melainkan hak karyawan, maka hotel yang bertindak sebagai perantara akan mencatat pada pos hutang service charge. Waktu pengakuannya pada saat hotel melakukan penagihan kepada subjek pajak.

Jurnal yang dibuat pada saat pemungutan atau pada saat penagihan terjadi adalah :

\begin{tabular}{|c|c|}
\hline Kas / Piutang & $\mathrm{xxx}$ \\
\hline Pendapatan & \\
\hline Hutang Pajak & \\
\hline Service Charge & \\
\hline
\end{tabular}

Sedangkan jurnal yang terjadi pada saat penyetoran pajak hotel ke kas daerah adalah : Hutang Pajak $\quad$ xxx Kas $\quad \mathrm{xxx}$

Sedangkan jurnal yang terjadi pada saat pembagian service charge yang dipungut kepada karyawan adalah :
Service Charge
Kas
XXX
XXX 


\subsection{Penelitian Terdahulu}

Dita Kurnia Sari (2014) dalam penelitian Evaluasi Sistem dan Prosedur Pemungutan Pajak Hotel Dalam Upaya Mendukung Pengendalian Intern. Hasil penelitian menunjukkan Hasil penelitian menunjukkan bahwa pelaksanaan sistem dan prosedur pemungutan pajak hotel pada DISPENDA Kota Malang sudah berjalan dengan baik namun masih terdapat kekurangan. Pengendalian intern terhadap sistem pemungutan pajak hotel masih terdapat ketidaksesuaian dengan pedoman Peraturan Pemerintah Nomor 60 Tahun 2008 salah satunya perangkapan tugas yang dilakukan seksi pendaftaran dan pendataan..

Annisa Ayu Aprilia (2016) dalam penelitian Analisis Penerapan Sistem Akuntansi Penerimaan Pajak Hotel di DPPK Kota Surabaya. Hasil penelitian menunjukkan bahwa sistem penerimaan pajak hotel yang terdiri dari prosedur penerimaan, catatan-catatan dan dokumen pada DPPK Kota Surabaya sudah terlaksana berdasarkan Peraturan Pemerintah No. 71 Tahun 2010.

\section{METODE PENELITIAN}

\subsection{Jenis Penelitian}

Jenis penelitian ini yang digunakan dalam penelitian ini adalah penelitian kualitatif dengan melakukan pengkajian data dalam bentuk deskriptif atau berbentuk uraian.

\subsection{Tempat dan Waktu Penelitian}

Penelitian di laksanakan di PT. Sari Murni Putra (Big Fish Hotel Manado) yang berkedudukan di Jl. Piere Tendean No. 107-108 Boulevard Manado, Sulawesi Utara, Indonesia. Periode waktu penelitian di mulai pada bulan November 2017- Januari 2018.

\subsection{Prosedur Penelitian}

Adapun keterangan yang di lakukan dari tahap-tahap Prosedur Penelitian di atas adalah sebagai berikut.:

1. Survei Pendahuluan

2. Identifikasi Objek

3. Pengumpulan Data

4. Analisis Data

5. Hasil Penelitian

6. Kesimpulan dan Saran

\subsection{Metode Pengumpulan Data}

\section{Jenis Data}

1. Data Kualitatif adalah data yang menggunakan deskripsi prosedur secara naratif atau kata-kata, ungkapan atau pernyataan dan menyimpulkan hasil secara naratif atau katakata.

2. Data Kuantitatif adalah reduksi data menjadi angka-angka dan menyimpulkan hasil menggunakan statistik.

\section{Sumber Data}

1. Data Primer yaitu data yang diperoleh dari responden melalui hasil wawancara peneliti dengan narasumber.

2. Data Sekunder yaitu data yang didapat dari caatan, buku, majalah berupa laporan keuangan publikasi perusahaan, artikel dan buku-buku sebagai teori.

\subsection{Teknik Pengumpulan Data}

Teknik pengumpulan data di lakukan dengan 2 cara, yaitu:

1. Penelitian kepustakaan (library research).

2. Penelitian lapangan (field research)

a. Wawancara,

b. Observasi (Pengamatan)

Pemantauan prosedur-prosedur atau kebijakan yang dilaksanakan perusahaan 


\section{6. $\quad$ Metode Analisis}

Metode analisis data yang digunakan adalah metode deskriptif yang bersifat kualitatif yaitu suatu metode yang dilakukan dengan cara mengumpulkan, menyajikan, serta menganalisis data dan menguraikannya dengan kalimat sehingga diperoleh gambaran yang cukup jelas tentang masalah yang dihadapi, kemudian ditarik suatu kesimpulan mengenai prosedur pemungutan dan penerapan akuntansi pajak hotel apakah sesuai dengan peraturan pemerintah yang berlaku saat ini.

\section{HASIL PENELITIAN DAN PEMBAHASAN}

\subsection{Hasil Penelitian}

Prosedur pemungutan pajak hotel yang dilakukan Big Fish Hotel Manado yaitu :

Pelaksanaan Pemungutan

Proses pemungutan pajak hotel pada Big Fish Hotel Manado dilakukan langsung pada saat proses transaksi pembayaran (sudah termasuk pajak) yang terjadi dan dicatat oleh kasir kemudian langsung masuk di laporan keuangan perusahaan. Kemudian setiap awal bulan dilakukannya rekapitulasi pendapatan penjualan kamar oleh pihak akuntansi perusahaan untuk membuat laporan pajak dalam rangka memenuhi kewajiban wajib pajak perusahaan kepada Badan Pengelola Pajak dan Retribusi Daerah Kota Manado.

\section{Pelaksanaan Pelaporan}

Setelah melaksanakan perhitungan atas pajak hotel, selanjutnya Big Fish Hotel Manado akan melakukan pelaporan atas jumlah kewajiban pembayaran pajak hotel ke Badan Pengelola Pajak dan Retribusi Daerah Kota Manado dengan menggunakan Surat Pemberitahuan Pajak Daerah (SPTPD) dengan melampirkan laporan penjualan kamar. Batas akhir pelaporan 15 hari setelah berakhirnya masa pajak setiap bulan berjalan.

\section{Pelaksanaan Penyetoran}

Setelah dilakukan pelaporan ke Badan Pengelola Pajak dan Retribusi Daerah Kota Manado akan menerima Surat Ketetapan Pajak Daerah (SKPD) yang berisi jumlah pajak hotel terutang beserta tanggal jatuh tempo pembayaran, SKPD juga akan menjadi sarana dalam pembayaran pajak hotel. Pembayaran pajak hotel dapat dilakukan melalui Badan Pengelola Pajak dan Retribusi Daerah Kota Manado dan Bank Sulutgo.

Pengakuan, Pengukuran dan Pengungkapan Pendapatan Terhadap Pencatatan Akuntansi Pajak Hotel Pada Big Fish Hotel Manado

\section{Pengakuan Pendapatan} berikut :

Pengakuan pendapatan yang dilakukan pada Big Fish Hotel Manado adalah sebagai

a. Pendapatan Kamar (Room)

Pendapatan kamar diperoleh dari kamar yang terjual pada hari itu yang tercantum dalam laporan Daily Sales Report (DSR). Pembayaran memang dapat dilakukan dengan mekanisme deposit, pembayaran langsung atau pembayaran akumulasi penggunaan hunian kamar. Namun, dalam pengakuan pendapatan kamar adalah dilakukan setiap hari sesuai dengan penggunaan kamar yang terjual.

b. Pendapatan Restoran (Food and Beverage)

Pendapatan Food and Beverage dari breakfast diperoleh dari pembagian harga kamar (bukan room only), sehingga pengakuan pendapatan breakfast juga dilakukan setiap hari sesuai dengan penggunaan kamar yang terjual. Sedangkan pendapatan Food and Beverage dari Room Service disesuaikan dengan hasil penjualan yang terjadi pada saat itu.

c. Pendapatan Bunquet dan Pendapatan Sewa Hall

Pengakuan pendapatan dari Bunquet dan Sewa Hall diakui pada saat kegiatan tersebut dilaksanakan. 
d. Pendapatan Lain-iain

Pendapatan lain-lain berupa penggunaan fasilitas telepon dan fax oleh tamu, printing, penjualan materai, penjualan rokok dan pendapatan lain yang tidak tersedia pada akun yang telah dibuat. Pengakuan pendapatan lain-lain diakui pada saat terjadinya transaksi tersebut.

\section{Pengukuran Pendapatan}

Pengukuran pendapatan yang dilakukan pada Big Fish Hotel Manado :

Tabel Publish Price (Gross Income) dan Net Income

\begin{tabular}{|c|c|c|c|}
\hline No & Type Rooms & Publish Price & Net Income \\
\hline 1. & Superior Room & xxx & xxx \\
\hline 2. & Deluxe Room & xxx & xxx \\
\hline
\end{tabular}

Sumber : Data Diolah 2018

Harga publikasi (publish price) merupakan dasar gross income yang merupakan harga dasar atau full rate yang ditetapkan oleh manajemen Big Fish Hotel Manado sebelum menetapkan discount rate atau growth up rate untuk transaksi dan/atau waktu tertentu. Harga tersebut sudah termasuk (include) tax and service charge.

Tabel Tax and Service Charge

\begin{tabular}{|c|c|c|c|}
\hline No & Type Rooms & Tax & Service Charge \\
\hline 1. & Superior Room & $\mathrm{xxx}$ & $\mathrm{xxx}$ \\
\hline 2. & Deluxe Room & $\mathrm{xxx}$ & $\mathrm{xxx}$ \\
\hline
\end{tabular}

Sumber : Data Diolah 2018

Berdasarkan tabel di atas, maka dapat diketahui bahwa pengakuan dan pengukuran pendapatan dilakukan dengan menggunakan net income sehingga jurnal yang dibuat (untuk superior room) adalah sebagai berikut :

Berdasarkan tabel di atas, maka dapat diketahui bahwa pengakuan dan pengukuran pendapatan dilakukan dengan menggunakan net income sehingga jurnal yang dibuat (untuk superior room) adalah sebagai berikut :

1. Jurnal pada saat pemungutan atau pada saat penagihan terjadi :

\begin{tabular}{|c|c|c|c|}
\hline Tanggal & Keterangan & Debit & Kredit \\
\hline 01 Desember 20xx & Cash & $\mathrm{xxx}$ & \\
\hline & Tax & & $\mathrm{xxx}$ \\
\hline & Service Charge & & $\mathrm{xxx}$ \\
\hline & Breakfast & & $\mathrm{Xxx}$ \\
\hline & Room Revenue & & $\mathrm{xxx}$ \\
\hline
\end{tabular}

2. Jurnal pada saat penyetoran pajak hotel ke kas daerah per tanggal $\mathbf{1 0}$ bulan berikutnya :

\begin{tabular}{|c|c|c|c|}
\hline Tanggal & Keterangan & Debit & Kredit \\
\hline 10 Januari 20xx & Tax & $\mathrm{xxx}$ & \\
\hline & Cash & & $\mathrm{xxx}$ \\
\hline
\end{tabular}

3. Jurnal pada saat pembayaran service charge karyawan per tanggal 20 bulan berikutnya :

\begin{tabular}{|c|c|c|c|}
\hline Tanggal & Keterangan & Debit & Kredit \\
\hline 20 Januari 20xx & Service Charge & $\mathrm{xxx}$ & \\
\hline & Cash & & $\mathrm{xxx}$ \\
\hline
\end{tabular}

\section{Pengungkapan Pendapatan}

Pengungkapan yang dilakukan pada Big Fish Hotel Manado telah menyertakan kebijakan-kebijakan akuntansi dalam pengakuan pendapatan yaitu berdasarkan pada akrual basis dan pada setiap kategori pos-pos pendapatan telah diungkapkan menurut posnya 
masing-masing dalam laporan laba rugi perusahaan. Pada laporan perusahaan terdapat kategori untuk pengungkapan pendapatan yaitu pendapatan usaha dan pendapatan lain-lain, yang didalamnya telah mencakup setiap pos-pos yang telah disebutkan sebelumnya.

\subsection{Pembahasan}

Berdasarkan Peraturan Daerah Kota Manado Nomor 2 Tahun 2011 tentang Pajak Daerah, disebutkan bahwa pajak hotel dipungut dengan self assessment system, yaitu sistem pemungutan pajak yang memberikan kewenangan kepada wajib pajak untuk menghitung sendiri besarnya pajak terutang. Big Fish Hotel Manado telah melaksanakan pemungutan dengan melakukan pencatatan transaksi pembayaran yang terjadi, kemudian dilakukan perhitungan dan pemeriksaan pajak terutangnya berdasarkan SKPD dan membuat rekapan pendapatan kamar setiap awal bulannya. Apabila pihak hotel belum melakukan pemeriksaan dengan benar sesuai peraturan yang berlaku, maka harus dilakukan pemeriksaan kembali pencatatan dan perhitungan pajaknya. Sebaliknya jika pihak hotel telah melakukan pencatatan, perhitungan dan pemeriksaan dengan benar sesuai peraturan, pihak hotel mempersiapkan data perpajakannya. Selanjutnya pihak hotel melakukan pembayaran ke kas daerah melalui Bank yang telah ditentukan yaitu Bank Sulutgo dan pihak harus melakukan register untuk memperoleh SPTPD dan nomor SPTPD yang diberikan petugas dan diharuskan melaporkan besarnya pajak hotel terutang yang telah dihitung sendiri oleh wajib pajak berdasarkan omset penghasilan dengan melampirkan bukti pendukung seperti bill kamar hotel ke Badan Pengelola Pajak dan Retribusi Daerah Kota Manado setiap tanggal 10 bulan berjalan. Kemudian Badan Pengelola Pajak dan Retribusi Daerah Kota Manado menerima pelaporan dari pihak hotel dan mengembalikan rekapan SPTPD dan SSPD keapda pihak hotel yang selaknjutnya di arsipkan ke hotel.

Sumber pendapatan yang diperoleh perusahaan terdiri dari pendapatan kamar, pendapatan food and beverage, pendapatan bunquet, pendapatan sewa hall, serta pendapatan lain-lain. Pada prakteknya perusahaan melaksanakan pengakuan dan pengukuran terhadap konsep pendapatan yang telah diterapkan berdasarkan PSAK No. 23 tentang Akuntansi Pendapatan. Metode pengakuan yang digunakan perusahaan dalam metode accrual basic, dimana keuntungan diakui pada saat terjadinya transaksi. Pengukuran pendapatan dilakukan berdasarkan jumlah uang yang diterima dikurangi tax and service charge, sehingga diperhitungkan dengan nett income. pengakuan, pengukuran, dan pengungkapan pendapatan pada Hotel Big Fish Hotel Manado telah sesuai dengan Pernyataan Standar Akuntansi Keuangan (PSAK) No. 23 tentang akuntansi pendapatan. Penetapan harga publish (publish price) telah diperhitungkan kewajiban pajak hotel terutang untuk dibayarkan oleh pihak Big Fish Hotel Manado kepada Pemerintah Kota Manado, dengan tarif sebesar 10\% (sepuluh persen).

\section{PENUTUP}

\subsection{Kesimpulan}

Berdasarkan penelitian yang dilakukan oleh peneliti terhadap Prosedur Pemungutan

Pajak Hotel dan Penerapan Akuntansi Pajak Hotel pada Big Fish Hotel Manado adalah sebagah sebagai berikut :

1. Pemungutan, pelaporan dan penyetoran pajak yang dilakukan oleh Big Fish Hotel Manado telah sesuai dengan Undang-Undang Nomor 28 Tahun 2009 tentang Pajak Daerah dan Retribusi Daerah serta Peraturan Daerah Kota Manado Nomor 2 Tahun 2011 tentang Pajak Daerah yang berlaku saat ini.

2. Pengakuan, Pengukuran dan Pengungkapan Pendapatan atas Jasa Hotel pada Big Fish Hotel sudah sesuai berdasarkan Pernyataan Standar Akuntansi Keuangan (PSAK) No. 23 tentang Pendapatan yang berlaku saat ini. 


\subsection{Saran}

Berdasarkan hasil penelitian dan kesimpulan yang dilakukan peneliti pada Big Fish Hotel Manado, maka peneliti memberikan saran yaitu agar perusahaan tetap mempertahankan prosedur pemungutan pajak hotel yang telah dilakukan karena telah sesuai dengan Peraturan Daerah Kota Manado Nomor 2 Tahun 2011 dan dan penerapan akuntansi pajak hotel sudah sesuai dengan Pernyataan Standar Akuntansi Keuangan (PSAK) No. 23 yang berlaku saat ini.

\section{DAFTAR PUSTAKA}

Aprilia Anisa Ayu dan Praptoyo Sugeng, 2016. Analisis Penerapan Sistem Akuntansi Penerimaan Pajak Hotel di DPPK Kota Surabaya.

Horgren, Datar, Foster, George, 2013. Akuntansi Biaya Dengan Penekanan Manajerial. Jilid I. Edisi 12. Erlangga. Jakarta.

IAI, 2015. Pernyataan Standar Akuntansi Keuangan. Jakarta: Salemba Empat.

Lubis Irsan, 2015. Mahir Akuntansi Pajak Terapan Berbasis Standar Akuntansi \& Ketentuan Pajak Terbaru. Penerbit Andi. Yogyakarta.

Peraturan Daerah Kota Manado Nomor 2 Tahun 2011 tentang Pajak Daerah

Pontoh, Winston. 2013. Akuntansi Konsep dan Aplikasi. Halaman Moeka, Jakarta.

Priantara Diaz, 2013. Perpajakan Indonesia. Edisi 2 Revisi. Penerbit Mitra Wacana Media. Jakarta.

Puspita Silvani Dian, 2012. Pencatatan Akuntansi Atas Pajak Daerah Pada Hotel Novotel Semarang.

Sari Dita Kurnia, Saifi Muhammad dan Zahroh Z. A, 2014. Evaluasi Sistem Dan Prosedur Pemungutan Pajak Hotel Dalam Upaya Mendukung Pengendalian Intern.

Siahaan Marihot, 2016. Pajak Daerah dan Retribusi Daerah. Edisi Revisi. PT. Raja Grafindo Persada. Jakarta

Undang-Undang Nomor 28 Tahun 2009 tentang Pajak Daerah dan Retribusi Daerah

Wisanggeni Irwan, 2015. Pajak Di Beragam Sektor Usaha. Penerbit Indeks. Jakarta. 